\title{
PENGARUH EPS, ROE, ROA DAN DER TERHADAP HARGA SAHAM PADA PERUSAHAAN SUB SEKTOR SEMEN YANG TERDAFTAR DI BEI
}

\author{
Asep Alipudin \\ Dosen Tetap Fakultas Ekonomi Universitas Pakuan \\ Resi Oktaviani \\ Mahasiswa Fakultas Ekonomi Universitas Pakuan
}

\begin{abstract}
ABSTRAK
Tujuan penelitian yang ingin dicapai penulis dalam penelitian ini adalah untuk mengetahui pengaruh earning per share (EPS), return on equity (ROE), return on assets (ROA) dan debt to equity ratio $(D E R)$ terhadap harga saham pada perusahaan sub sektor semen yang terdaftar di BEI secara simultan. Ada pun uji yang digunakan adalah uji asumsi klasik, uji koefisien determinasi, uji t, dan uji F. Hasil pengujian menunjukkan earning per share (EPS), return on equity (ROE), return on assets (ROA) dan debt to equity ratio (DER) secara bersama-sama berpengaruh positif terhadap harga saham pada perusahaan semen yang terdaftar di Bursa Efek Indonesia (BEI) periode 2010-2014.
\end{abstract}

Kata kunci: Earning per Share (EPS), Return on Equity (ROE), Return on Assets (ROA), dan Debt to Equity Ratio (DER)

\section{ABSTRACT}

The purpose of this study was to determine the effect of earnings per share (EPS), return on equity $(R O E)$, return on assets (ROA) and debt to equity ratio (DER) to the price of shares in the sub-sector of cement which is listed on the Stock Exchange simultaneously. There is also the test used is the classic assumption test, test the coefficient of determination, $t$ test, and $F$ test results show earnings per share (EPS), return on equity (ROE), return on assets (ROA) and debt to equity ratio (DER) jointly positive effect on stock prices at a cement company listed on the Indonesia stock Exchange (BEI) in the period 2010-2014.

Keywords: Earning per Share (EPS), Return on Equity (ROE), Return on Assets (ROA), dan Debt to Equity Ratio (DER)

\section{Pendahuluan}

Perkembangan industri semen di Indonesia terus mengalami peningkatan. Industri semen adalah salah satu industri yang sangat penting dalam menunjang pembangunan sebuah negara. Tinggi rendahnya konsumsi semen menunjukkan tinggi rendahnya pembangunan infrastruktur di suatu negara. Semen merupakan komponen utama dalam pembangunan infrastruktur, seperti gedung, jalan tol, pelabuhan, bandara, jembatan dan berbagai infrastruktur lainnya. Indonesia merupakan negara yang sedang berkembang di mana pembangunan infrastruktur dari tahun ke tahun semakin meningkat, maka seiring dengan itu kebutuhan semen pun akan terus meningkat (www.kompasiana.com).

Pada tahun 2015 ini penjualan semen dalam negeri ditargetkan mencapai 62 juta ton. Pertumbuhan konsumsi semen pada tahun ini akan ditopang oleh proyek-proyek pemerintah, seperti trans sumatera, tol Manado-Bitung, tol Medan-Kuala $\mathrm{Namu}$, pembangunan pembangkit listrik dan PLTU, proyek MRT hingga 
pembangunan pelabuhan di seluruh nusantara (sumber: www.neraca.co.id).

Semakin pesatnya perkembangan perusahaan semen di Indonesia, maka semakin ketat pula persaingan yang terjadi. Oleh sebab itu menuntut setiap perusahaan untuk meningkatkan kinerja perusahaan agar tetap eksis dalam menghadapi persaingan serta melakukan pengembangan dan perluasan bidang usaha.

Salah satu faktor pendukung untuk kelangsungan suatu industri adalah tersedianya dana. Pemenuhan kebutuhan dana dapat diperoleh dengan melakukan pinjaman dalam bentuk hutang atau menerbitkan saham di pasar modal. Instrumen pasar modal yang paling sering diperdagangkan adalah saham. Saham dari perusahaan yang menjualnya ke publik adalah saham yang diperjualbelikan pada masyarakat umum (investor) pada suatu bursa saham. Bursa efek yang mengatur transaksi pembelian dan penjualan saham di Indonesia adalah Bursa Efek Indonesia (BEI).

Pada saat terjadi transaksi penjualan dan pembelian saham, biasanya para investor sangat memperhatikan harga saham karena harga saham menunjukkan nilai suatu perusahaan. Sehingga sering kali dikatakan memaksimumkan nilai perusahaan juga memaksimumkan kekayaan pemegang saham. Harga saham yang cukup tinggi akan memberikan return bagi para investor berupa capital gain yang akhirnya akan berpengaruh terhadap citra perusahaan.
Saham merupakan instrument investasi yang banyak dipilih para investor karena saham mampu memberikan tingkat keuntungan yang menarik. Saham tidak hanya memberikan keuntungan atau manfaat kepada para investor, tetapi saham juga tidak lepas dari risiko. Sesuai dengan karakteristik saham yaitu high risk high return atau semakin tinggi tingkat keuntungan maka semakin tinggi pula risikonya, maksudnya adalah seorang investor bisa mendapatkan keuntungan yang sangat besar dalam sekejap, namun seiring dengan berfluktuasinya harga saham maka saham juga membuat investor mengalami kerugian besar dalam waktu singkat.

Untuk itu ketika investor melakukan investasi dalam bentuk saham, maka investor memerlukan informasi sebagai bahan pertimbangan dan penilaian tentang kinerja perusahaan dan kemungkinan dampak atau hubungannya dengan harga saham, salah satunya menggunakan analisis fundamental, dengan menitikberatkan pada data-data kunci dalam laporan keuangan untuk memperhitungkan apakah harga saham sudah diapresiasi secara akurat. Dalam analisis ini biasanya para investor menggunakan rasio keuangan untuk memprediksi harga saham.

Berikut disajikan perkembangan harga saham perusahaan sub sektor semen yang terdaftar di BEI periode 2010-2014. 


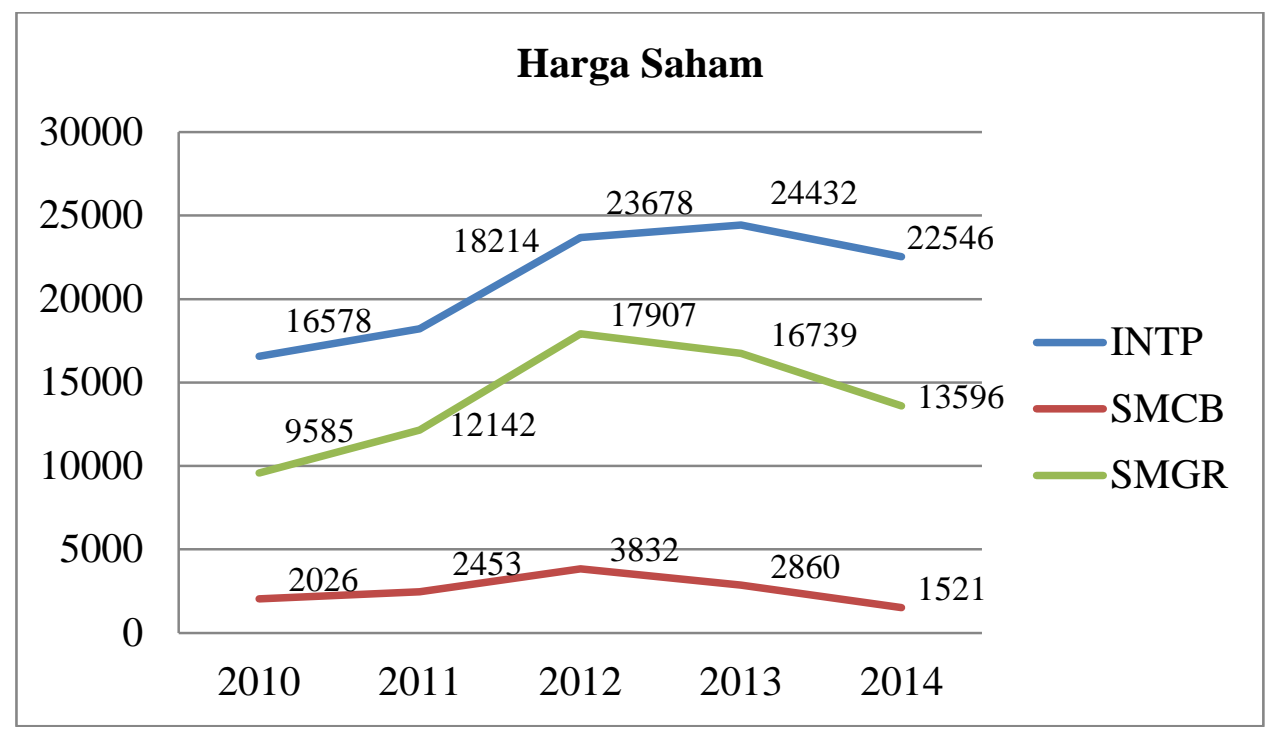

(Sumber: $\underline{w w w}$.yahoofinance.com diolah oleh penulis,2015)

\section{Gambar 1.}

Perkembangan Harga Saham pada Perusahaan Sub Sektor Semen 2010-2014

Dari grafik perkembangan harga saham di atas, dapat dilihat bahwa harga saham perusahaan sub sektor semen mengalami fluktuasi setiap tahunnya dan semua perusahaan mengalami penurunan harga saham pada tahun 2014. Penurunan harga saham yang terjadi pada tahun 2014 tersebut dikarenakan adanya kebijakan pemerintah untuk menurunkan harga semen. Penurunan harga semen ini disinyalir agar pembangunan infrastruktur lebih baik. Kebijakan tersebut untuk membantu pemerintah dalam mempercepat proses pembangunan infrastruktur. Penurunan harga jual akan diikuti dengan penurunan biaya produksi dan akan mempengaruhi pembagian dividen yang lebih kecil dibandingkan dengan pembagian sebelumnya. Namun dengan penurunan harga saham yang terjadi, saham sub sektor semen masih direkomendasikan untuk dibeli. Sebab, kebijakan pemerintah yang akan meningkatkan belanja infrastruktur akan dengan mudah membuat konsumsi semen mengalami peningkatan. (www.medanbisnisdaily.com)
Jumlah permintaan atas saham akan mempengaruhi harga saham. Jika permintaan atas saham tinggi maka harga saham akan naik, namun apabila permintaan akan saham rendah maka harga saham akan turun. Fluktuasi harga saham dipengaruhi oleh banyak faktor sehingga perlu diteliti secara lebih lanjut faktor-faktor apa saja yang menjadi penyebabnya.

Adapun tujuan penelitian yang ingin dicapai penulis dalam penelitian ini adalah sebagai berikut: 1) Untuk mengetahui perkembangan earning per share (EPS), return on equity (ROE), return on assets (ROA) dan debt to equity ratio (DER) pada perusahaan sub sektor semen yang terdaftar di BEI; 2) Untuk mengetahui perkembangan harga saham pada perusahaan sub sektor semen yang terdaftar di BEI; 3) Untuk mengetahui pengaruh earning per share $(E P S)$, return on equity (ROE), return on assets (ROA) dan debt to equity ratio (DER) terhadap harga saham pada perusahaan sub sektor semen yang terdaftar di BEI secara parsial; dan 4) Untuk mengetahui pengaruh earning per share (EPS), return on equity (ROE), 
return on assets (ROA) dan debt to equity ratio $(D E R)$ terhadap harga saham pada perusahaan sub sektor semen yang terdaftar di BEI secara simultan.

\section{Tinjauan Pustaka}

\subsection{Analisis Kinerja Perusahaan}

Keberhasilan suatu perusahaan dalam mencapai tujuan dan memenuhi kebutuhan masyarakat sangat tergantung kepada kinerja perusahaan dan manajer perusahaan dalam melaksanakan semua tanggung jawabnya. Kinerja keuangan dapat diartikan sebagai prestasi organisasi atau perusahaan dinilai secara kuantitatif dalam bentuk uang yang dilihat dari segi pengelolaannya, pergerakannya maupun tujuannya. Penilaian kinerja menurut Mulyadi $(2009,415)$ adalah penentuan secara periodik efektivitas operasional suatu organisasi, bagian organisasi dan karyawan berdasarkan sasaran, standar dan kriteria yang telah ditetapkan sebelumnya.

Penilaian kinerja mengandung makna suatu sistem pengukuran mengenai pelaksanaan kemampuan kinerja suatu organisasi. Jadi pada prinsipnya penilaian kinerja bertujuan untuk meningkatkan kinerja perusahaaan melalui suatu proses yaitu cara atau tolak ukur kinerja perusahaaan.

Penilaian kinerja dikembangkan untuk memberikan beberapa petunjuk pada para manajer dan untuk mengevaluasi kinerja. Perkembangan alat ukur penilaian kinerja dan spesifikasi struktur penghargaan merupakan hal utama dalam organisasi atau perusahaan. Karena alat ukur penilaian kinerja dapat mempengaruhi perilaku para manajer. Penilaian kinerja dapat mendukung tingkat keserasian tujuan. Dengan kata lain, kinerja berpengaruh dalam mewujudkan tujuan perusahaan.
Kinerja perusahaan dapat digambarkan melalui laporan keuangan. Laporan keuangan merupakan salah satu sumber informasi penting bagi para pengguna laporan keuangan dalam rangka pengambilan keputusan ekonomi untuk memprediksi yang terjadi pada perusahaan pada masa yang akan datang. Oleh karena itu para pengguna laporan keuangan perlu melihat dan mengidentifikasi performa perusahaan melalui laporan keuangan selama periode tertentu yang digunakan sebagai alat ukur dalam menilai kinerja keuangan.

Tingkat kesehatan perusahaan dapat diketahui dengan melakukan analisis terhadap laporan keuangan. Analisis laporan keuangan adalah analisis keuangan yang terdiri dari penelaahan atau mempelajari hubungan atau kecenderungan untuk menentukan posisi keuangan dan hasil operasi serta perkembangan perusahaan yang bersangkutan. Analisis laporan keuangan berarti menguraikan akun-akun laporan keuangan menjadi unit informasi yang lebih kecil dan melihat hubungannya yang bersifat signifikan atau yang mempunyai makna antara yang satu dengan yang lain baik antara data kuantitatif maupun data non kuantitaif dengan tujuan untuk mengetahui kondisi keuangan lebih dalam yang sangat penting dalam proses menghasilkan keputusan yang tepat.

"Analisis laporan keuangan pada dasarnya merupakan pehitungan rasiorasio untuk menilai keadaan keuangan perusahaan di masa lalu, saat ini, dan kemungkinannya di masa depan." (Harahap, 2009, 190).

Berdasarkan penjelasan tersebut, dapat disimpulkan bahwa analisis laporan keuangan merupakan proses untuk mempelajari data-data keuangan agar dapat dipahami dengan mudah untuk mengetahui posisi keuangan, hasil 
operasi dan perkembangan suatu perusahaan dengan cara mempelajari hubungan data keuangan serta kecenderungannya terdapat dalam suatu laporan keuangan, sehingga analisis laporan keuangan dapat dijadikan sebagai dasar dalam pengambilan keputusan bagi pihak-pihak yang berkepentingan dan juga dalam melakukan analisisnya tidak akan lepas dari peranan rasio-rasio keuangan. Dengan melakukan analisis terhadap rasio-rasio keuangan akan dapat menentukan suatu keputusan yang akan diambil. Beberapa jenis rasio keuangan yang bisa digunakan dalam melakukan analisis laporan keuangan-yaitu rasio Earning Per Share (EPS), Return On Equity (ROE), Return On Assets (ROA) dan Debt to Equity Ratio (DER).

\subsubsection{Earning Per Share (EPS)}

Bagi para investor, informasi EPS merupakan informasi yang dianggap paling mendasar dan berguna, karena bisa menggambarkan prospek earning perusahaan di masa depan serta sebagai ukuran keefisienan suatu perusahaan. Menurut Kasmir (2012, 207) EPS merupakan rasio untuk mengukur keberhasilan manajemen dalam mencapai keuntungan bagi pemegang saham.

Dengan demikian, laba per lembar saham (EPS) menunjukan kemampuan perusahaan dalam memperoleh laba dan mendistribusikan laba yang diraih perusahaan kepada pemegang saham. Laba per lembar saham (EPS) dapat dijadikan sebagai indikator tingkat nilai perusahaan. Laba per lembar saham (EPS) juga merupakan salah satu cara untuk mengukur keberhasilan dalam mencapai keuntungan bagi para pemilik saham dalam perusahaan.

Semakin kecil nilai laba per saham maka semakin kecil pula kemungkinan perusahaan untuk membagikan dividen. Maka dapat dikatakan investor akan lebih meminati saham yang memiliki earning per share tinggi dibandingkan saham yang memiliki earning per share rendah. Earning per share yang rendah cenderung membuat harga saham turun, begitupun sebaliknya.

EPS dapat dihitung dengan menggunakan rumus:

Earning Per Share $=\frac{\text { Earning After Tax }(E A T)}{\text { Jumlah saham beredar }}$

(Irham Fahmi,2014,336)

Penggunaan rumus EPS pada umumnya akan lebih bermanfaat jika dibandingkan dengan periode-periode sebelumnya sehingga analisis akan menjadi lebih luas. Untuk keperluan analisis yang baik, perbandingan tidak hanya dilakukan pada tahun-tahun sebelumnya, tetapi dengan industri yang sejenis.

\subsubsection{Return On Equity (ROE)}

Dalam mengukur kinerja perusahaan, investor biasanya melihat kinerja keuangan yang tercermin dari berbagai macam rasio. Return on Equtity (ROE) merupakan salah satu indikator penting yang sering digunakan oleh investor untuk menilai tingkat profitabilitas perusahaan sebelum melakukan investasi.

Menurut Gitman (2012, 82) ROE secara umum mengukur pengembalian yang diperoleh atas investasi pemegang saham biasa di perusahaan. Sedangkan menurut Irham Fahmi (2014, 338) ROE 
adalah rasio yang digunakan untuk mengkaji sejauh mana suatu perusahaan mempergunakan sumber daya yang dimiliki untuk mampu memberikan laba atas ekuitas.

Dengan demikian dapat disimpulkan bahwa ROE adalah untuk mengetahui sejauh mana investasi yang akan dilakukan investor di suatu perusahaan mampu memberikan return yang sesuai dengan tingkat yang disyaratkan oleh investor. Apabila return on equity yang dimiliki suatu perusahaan semakin tinggi, maka semakin tinggi pula jumlah laba bersih yang dihasilkan dari setiap rupiah dana yang tertanam dalam ekuitas, dan sebaliknya.

Menurut Irham Fahmi (2014,338), ROE dapat diformulasikan sebagai berikut:

$$
\text { Return On Equity }=\frac{\text { Earning After } \text { Tax }(E A T)}{\text { Total Equity }}
$$

Dengan demikian, rasio ini menghubungkan laba bersih yang diperoleh dari operasi perusahaan dengan jumlah modal sendiri yang dimiliki. Apabila return on equity semakin tinggi, maka suatu perusahaan memiliki peluang untuk memberikan pendapatan yang besar bagi para pemegang saham. Dalam hal ini akan berdampak pada peningkatan harga saham.

\subsubsection{Return On Assets (ROA)}

Salah satu rasio keuangan yang banyak digunakan untuk mengukur kinerja perusahaan khususnya menyangkut profitabilitas perusahaan adalah return on assets (ROA) atau hasil pengembalian atas aset. ROA menujukkan keefisienan perusahaan dalam mengelola seluruh aktivanya untuk memperoleh pendapatan.

Return on assets memberikan indikasi seberapa efisien suatu perusahaan dalam menggunakan total aset mereka untuk menghasilkan laba. Semakin besar rasio ini maka perusahaan lebih efisien dalam penggunaan aset. Sangat penting untuk mengambil ratarata total aset karena aset cenderung sering berubah setiap periodenya.
Menurut kasmir $(2012,201)$ menyatakan bahwa ROA adalah rasio yang menunjukkan hasil (return) atas jumlah aktiva yang digunakan dalam perusahaan. Selain itu, ROA memberikan ukuran yang lebih baik atas profitabilitas perusahaan karena menunjukkan efektifitas manajemen dalam menggunakan aktiva untuk memperoleh pendapatan. Menurut Gitman $(2012,81)$ ROA adalah untuk mengukur kefektifan manajemen dalam menghasilkan laba dengan aset yang tersedia.

Dapat disimpulkan bahwa rasio ini digunakan untuk mengukur kemampuan manajemen perusahaan dalam memperoleh keuntungan (laba) secara keseluruhan berdasarkan jumlah aktiva yang digunakan. Dengan kata lain, semakin tinggi rasio ini maka semakin baik produktivitas aset dalam memperoleh keuntungan bersih. Hal ini selanjutnya akan meningkatkan daya tarik perusahaan dan menjadikan perusahaan tersebut semakin diminati oleh investor, karena tingkat pengembalian akan semakin besar. Rasio ini akan berpengaruh terhadap harga saham perusahaan.

Menurut Kamir $(2012,202)$ ROA dapat dihitung dengan menggunakan : 


$$
\text { Return On Assets }=\frac{\text { EarningAfter Interest and Tax }}{\text { Total Assets }}
$$

Dari perhitungan di atas dapat disimpulkan bahwa seberapa besar pengembalian atas investasi yang dihasilkan oleh perusahaan dengan membandingkan laba usaha dengan total asset atau operating assets. Oleh karena itu, semakin besar rasio semakin baik karena berarti semakin besar kemampuan perusahaan dalam menghasilkan laba.

\subsubsection{Debt to Equity Ratio (DER)}

Istilah leverage mengacu pada penggunaan aset dan sumber dana oleh perusahaan dimana dalam penggunaan aset atau dana tersebut perusahaan harus mengeluarkan biaya tetap atau beban tetap. Penggunaan aset (aktiva) atau dana tersebut pada akhirnya dimaksudkan untuk meningkatkan keuntungan potensial bagi pemegang saham.Salah satu alat ukur untuk menghitung leverage ratio dapat diukur dengan menggunakan debt to equity ratio (DER) atau rasio utang terhadap ekuitas.
Debt to equity ratio merupakan rasio yang digunakan untuk menilai utang dengan ekuitas. Rasio ini dicari dengan cara membandingkan antara seluruh hutang, termasuk hutang lancar dengan seluruh ekuitas. Rasio ini digunakan untuk mengetahui jumlah dana yang disediakan peminjam (kreditor) dengan pemilik perusahaan. Dengan kata lain, rasio ini berfungsi untuk mengetahui setiap rupiah modal sendiri yang dijadikan untuk jaminan utang (Kasmir,2014,157).

Dapat disimpulkan bahwa debt to equity ratio (DER) menunjukkan bagian dari setiap rupiah modal sendiri yang dijadikan jaminan utang yang dimiliki perusahaan. Semakin tinggi rasio ini berarti semakin besar dana yang diambil dari luar. Ditinjau dari sudut solvabilitas, rasio yang tinggi relatif kurang baik, karena bila terjadi likuidasi, perusahaan akan mengalami kebangkrutan.

Menurut Irham Fahmi (2014,76), DER dapat dihitung dengan menggunakan rumus:

$$
\text { Debt to Equity Ratio }=\frac{\text { Total Liabilities }}{\text { Total Equity }}
$$

\subsection{Pengembangan Hipotesis}

Salah satu sumber dana yang menjadi pilihan bagi perusahaan yaitu dengan menjual saham atau kepemilikan perusahaan kepada publik. Para investor biasanya sangat tertarik pada saham yang menawarkan tingkat pertumbuhan dari pendapatan yang akan mereka terima. Jika para investor mengetahui dengan pasti laba yang akan perusahaan raih, maka mereka dapat mengestimasi harga saham perusahaan dimasa yang akan datang dan besarnya dividen yang akan mereka terima. Dengan demikian return pemegang saham akan menyangkut dengan prestasi perusahaan di masa depan, karena harga saham yang diharapkan oleh pemodal merupakan nilai intrinstik yang menunjukkan 
prestasi dan risiko saham tersebut di masa yang akan datang.

Analisis dan memilih saham dapat dilakukan melalui dua pendekatan dasar, yaitu analisis fundamental dan analisis teknikal (Jogiyanto,2010). Analisis fundamental sebagai salah satu pendekatan yang mempelajari antara harga saham dengan kondisi perusahaan. Analisis ini menitikberatkan pada rasio keuangan dan kejadian-kejadian secara langsung maupun tidak langsung mempengaruhi kinerja keuangan perusahaan. Kondisi keuangan suatu perusahaan merupakan faktor yang penting untuk berinvestasi dalam saham. Perusahaan yang mampu menghasilkan laba yang besar akan sangat diminati oleh investor.

EPS merupakan komponen penting pertama yang harus diperhatikan dalam analisis perusahaan. Informasi EPS suatu perusahaan menunjukkan besarnya laba bersih perusahaan yang siap dibagikan untuk semua pemegang saham perusahaan. Pada umumnya dalam menanamkan modalnya investor mengharapkan manfaat yang akan dihasilkan dalam bentuk laba per lembar saham EPS. Sedangkan jumlah laba per lembar saham EPS yang didistribusikan kepada para investor tergantung pada kebijakan perusahaan dalam hal pembayaran dividen. Laba per lembar saham EPS dapat menunjukan tingkat kesejahteraan perusahaan, jadi apabila laba per lembar saham EPS tinggi maka menandakan bahwa perusahaan tersebut mampu memberikan tingkat kesejahteraan yang baik kepada pemegang saham dan akan semakin banyak investor yang mau membeli saham tersebut sehingga menyebabkan harga saham akan tinggi (Galih Prasetyo,2011). Pernyataan tersebut diperkuat oleh hasil penelitian Debi Indah (2012), Ema Novasari (2013), Muhammad Irsyadul Ibad (2012) dan
Taranika Intan (2009) yang menemukan bahwa EPS berpengaruh positif dan signifinkan terhadap harga saham.

Return on equity (ROE) adalah rasio profitabilitas yang membandingkan antara laba bersih (net profit) perusahaan dengan aset bersihnya (ekuitas atau modal). Rasio ini mengukur seberapa banyak keuntungan yang dihasilkan oleh perusahaan dibandingkan dengan modal yang disetor oleh pemegang saham.

Semakin tinggi nilai ROE, maka semakin banyak investor yang tertarik dengan saham tersebut karena tingkat pengembalian yang akan didapatkan oleh investor akan semakin besar. Semakin banyak investor yang mencari saham di perusahaan yang mempunyai nilai ROE tinggi, maka harga saham akan naik seiring dengan bertambahnya permintaan dan penawaran di pasar sekunder. Panelitian Muhammad Irsyadul Ibad (2012) menguji pengaruh dari rasio return on equity berpengaruh positif dan signifikan terhadap harga saham.

Return on assets (ROA) adalah rasio yang membagi antara laba bersih setelah pajak dengan total aset. Rasio ini digunakan untuk melihat kemampuan perusahaan dalam mengelola setiap nilai aset yang mereka miliki untuk menghasilkan laba bersih setelah pajak.

Rasio ini mengukur tingkat pengembalian investasi yang telah dilakukan perusahaan dengan menggunakan seluruh aktiva yang dimilikinya. Semakin tinggi ROA semakin tinggi keuntungan. Semakin tinggi keuntungan yang dihasilkan perusahaan akan menjadikan investor tertarik akan nilai saham. Apabila dikaitkan dengan harga saham, maka semakin tinggi ROA semakin tinggi pula harga saham perusahaan tersebut karena tingkat keuntungan yang tinggi (Ema Novasari,2013). Pernyataan tersebut diperkuat oleh hasil penelitian 
Muhammad Irsyadul Ibad (2012) yang menemukan bahwa ROA berpengaruh postif terhadap harga saham.

Debt to equity ratio (DER) merupakan rasio solvabilitas yang mengukur kemampuan kinerja perusahaan dalam mengembalikan hutang jangka pendek maupun jangka panjangnya dengan melihat perbandingan antara total hutang dengan total ekuitasnya. Rasio ini sering digunakan para analis dan para investor untuk melihat seberapa besar hutang perusahaan jika dibandingkan ekuitas yang dimiliki oleh perusahaan atau para pemegang saham. Jika DER perusahaan tinggi, ada kemungkinan harga saham perusahaan akan rendah karena pada saat perusahaan memperoleh laba, perusahaan cenderung menggunakan laba tersebut untuk membayar hutangnya dibandingkan dengan membagi dividen. Hasil penelitian Ema Novasari (2013) menunjukkan bahwa DER memiliki pengaruh terhadap harga saham, sedangkan Debi Indah (2012) menunjukkan bahwa DER tidak memiliki pengaruh terhadap harga saham.

Berdasarkan pemikiran tersebut, maka kerangka berpikir dalam penelitian ini dapat dikemukakan bahwa harga saham (Y) dipengaruhi oleh earning per share (EPS) $\left(\mathrm{X}_{1}\right)$, return on equity $(\mathrm{ROE})\left(\mathrm{X}_{2}\right)$, return on assets $(\mathrm{ROA})\left(\mathrm{X}_{3}\right)$ dan debt to equity ratio (DER) $\left(\mathrm{X}_{4}\right)$.

Hipotesis penelitian yang dapat penulis ambil dalam penelitian ini adalah sebagai berikut:

- Hipotesis 1 : EPS, ROE dan ROA berpengaruh positif secara parsial terhadap harga saham.

- Hipotesis 2 : DER berpengaruh negatif secara parsial terhadap harga saham.

- Hipotesis 3 : EPS, ROE, ROA dan $D E R$ berpengaruh positif secara simultan terhadap harga saham.

\section{Metodologi Penelitian}

3.1. Objek, Unit Analisis dan Lokasi Penelitian

Objek penelitian dalam penelitian ini adalah variabel-variabel yang meliputi earning per share (EPS), return on equity (ROE), return on assets (ROA) dan debt to equity ratio (DER) serta pengaruhnya terhadap harga saham. Untuk memperoleh data dan informasi yang diperlukan maka penulis melakukan penelitian atas variabelvariabel tersebut pada perusahaan sub sektor semen yang terdaftar di BEI.

Unit analisis yang digunakan dalam penelitian ini adalah berupa organization, yaitu sumber data yang unit analisisnya merupakan respon dari divisi organisasi atau perusahaan. Dalam hal ini unit analisis adalah divisi organisasi yaitu perusahaan-perusahaan sub sektor semen yang terdaftar di BEI.

\subsection{Operasionalisasi Variabel}

Untuk memudahkan proses analisis, maka terlebih dahulu penulis mengklasifikasikan variabel-variabel penelitian, yaitu sebagai berikut: 
Tabel 3.

Operasionalisasi Variabel

Pengaruh Earning Per Share (EPS), Return On Equity (ROE), Return On Assets (ROA) dan Debt to Equity Ratio (DER) terhadap Harga Saham pada Perusahaan

Sub Sektor Semen yang Terdaftar di BEI

\begin{tabular}{|c|c|c|c|}
\hline $\begin{array}{l}\text { Variabel/Sub } \\
\text { Variabel }\end{array}$ & Indikator & Ukuran & Skala \\
\hline $\begin{array}{l}\text { Variabel X: } \\
\text { EPS }\left(X_{1}\right)\end{array}$ & $\begin{array}{l}\text { - Laba bersih setelah } \\
\text { pajak } \\
\text { - Jumlah saham yang } \\
\text { beredar }\end{array}$ & $\frac{\text { Earning After Tax }(E A T)}{\text { Jumlah saham beredar }}$ & Rasio \\
\hline $\operatorname{ROE}\left(\mathrm{X}_{2}\right)$ & $\begin{array}{l}\text { - Laba bersih setelah } \\
\text { pajak } \\
\text { - Total ekuitas }\end{array}$ & $\frac{\text { Earning After Tax }(E A T)}{\text { Shareholderequity }}$ & Rasio \\
\hline $\operatorname{ROA}\left(\mathrm{X}_{3}\right)$ & $\begin{array}{l}\text { - Laba bersih setelah } \\
\text { pajak } \\
\text { - Total aset }\end{array}$ & $\frac{\text { Earning After } \operatorname{Tax}(E A T)}{\text { Total aset }}$ & Rasio \\
\hline $\operatorname{DER}\left(\mathrm{X}_{4}\right)$ & $\begin{array}{l}\text { - Total kewajiban } \\
\text { - Total ekuitas } \\
\end{array}$ & $\frac{\text { Utang(lancar + panjang) }}{\text { Ekuitas }}$ & Rasio \\
\hline $\begin{array}{l}\text { Variabel Y : } \\
\text { Harga Saham }\end{array}$ & Pergerakan harga saham & $\begin{array}{l}\text { Rata-rata harga saham pada } \\
\text { bulan April (closing price) }\end{array}$ & Rasio \\
\hline
\end{tabular}

\subsection{Metode Penarikan Sampel}

Dalam penelitian ini populasi yang diambil adalah semua perusahaan sub sektor semen di BEI dengan periode 2010-2014 yaitu sebanyak lima perusahaan.Sampel dalam penelitian ini diambil dengan menggunakan metode purposive sampling, artinya pengambilan sampel yang didasarkan atas pertimbangan-pertimbangan tertentu dari peneliti. Dalam penelitian ini sampel yang diambil adalah tiga perusahaan sub sektor semen pada tahun 2010-2014. Sampel yang dipilih dalam penelitian ini adalah perusahaan sub sektor semen di BEI dengan kriteria sebagai berikut:

1. Perusahaan yang sudah terdaftar di BEI yang mempunyai data keuangan yang lengkap dan dapat diandalkan kebenarannya dari periode 20102014.
2. Perusahaan yang saham-sahamnya aktif diperdagangkan di BEI pada tahun 2010-2014.

3. Perusahaan tidak dalam keadaan rugi selama periode penelitian.

\subsection{Metode Pengolahan atau Analisis Data}

Data yang telah dikumpulkan mengenai semua variabel penelitian kemudian diolah atau dianalisis dengan analisis regresi linier berganda dengan bantuan Statistical Product Service Solution (SPSS) 20. Selanjutnya dilakukan beberapa uji asumsi klasik. Tetapi sebelumnya dilakukan analisis statistik deskriptif terlebih dahulu. Formulasi persamaan analisis regresi linier berganda dalam penelitian ini adalah sebagai berikut (Duwi Priyatno, 2012, 136):

$$
Y=a+b_{1} X_{1}+b_{2} X_{2}+b_{3} X_{3}+b_{4} X_{4}+e
$$


Dimana :

$$
\begin{aligned}
& \mathrm{Y}=\text { Variabel harga saham } \\
& \mathrm{a}=\text { Konstanta } \\
& \mathrm{b}_{1}=\text { Koefisien regresi untuk earning per share }(E P S) \\
& \mathrm{X}_{1}=\text { Earning per share }(E P S) \\
& \mathrm{b}_{3}=\text { Koefisien regresi untuk return on equity }(R O E) \\
& \mathrm{X}_{2}=\text { Return on equity }(R O E) \\
& \mathrm{b}_{3}=\text { Koefisien regresi untuk return on assets }(R O A) \\
& \mathrm{X}_{3}=\text { Return on assets }(R O A) \\
& \mathrm{b}_{4}=\text { Koefisien regresi untuk debt to equity ratio }(D E R) \\
& \mathrm{X}_{4}=\text { Debt to equity ratio }(D E R) \\
& \mathrm{e}=\text { Error }
\end{aligned}
$$

Langkah-langkah analisis data dan pengujian hipotesis yang akan dilakukan adalah sebagai berikut:

1. Uji Asumsi Klasik, yaitu sebuah model regresi yang baik adalah model dengan kesalahan peramalan yang seminimal mungkin. Karena itu, sebuah model sebelum digunakan seharusnya memenuhi beberapa asumsi, yang biasa disebut dengan asumsi klasik. Harus terpenuhinya asumsi klasik ditujukan untuk memperoleh model regresi dengan estimasi yang tidak bias dan pengujian dapat dipercaya. (Duwi Priyatno, 2012, 146). Beberapa asumsi yang umumnya digunakan, antara lain: 1) Uji Normalitas; 2) Uji Heteroskedastisitas; 3) Uji Multikolinieritas; dan 4) Uji Autokorelasi

2. Uji Hipotesis dengan menggunakan Analisis
Determinasi, Uji t (Uji Koefisien Regresi Secara Parsial), dan Uji F (Uji Koefisien Regresi Secara Bersama-sama).

IV. Hasil dan Pembahasan

4.1. Hasil Penelitian

4.1.1. Perkembangan EPS, ROE, ROA dan $D E R$ pada Perusahaan Sub Sektor Semen yang terdaftar di BEI

Berikut perkembangan earning per share (EPS), return on equity (ROE), return on assets (ROA) dan debt to equity ratio ( $D E R$ ) pada perusahaan sub sektor semen yang terdaftar di BEI periode 2010-2014:

1. Perkembangan EPS pada Perusahaan Sub Sektor Semen

Berdasarkan hasil penelitian yang dilakukan, perkembangan earning per share pada perusahaan sub sektor semen periode 20102014 adalah sebagai berikut:

Tabel 21.

Perkembangan Earning Per Share (EPS)

Perusahaan Sub Sektor Semen Periode 2010-2014

(satuan rupiah)

\begin{tabular}{|c|c|c|c|}
\hline TAHUN & INTP & SMCB & SMGR \\
\hline $\mathbf{2 0 1 0}$ & 876.05 & 108 & 613 \\
\hline $\mathbf{2 0 1 1}$ & 977.1 & 139 & 662 \\
\hline $\mathbf{2 0 1 2}$ & 1293.15 & 176 & 817 \\
\hline $\mathbf{2 0 1 3}$ & 1361.02 & 124 & 905 \\
\hline
\end{tabular}


2014

1431.82

87

938

(Sumber: $\underline{w w w . i d x . c o . i d ~ d i o l a h ~ o l e h ~ p e n u l i s, ~ 2016) ~}$

Perkembangan EPS pada perusahaan sub sektor semen pada periode 2010-2014 menghasilkan tingkat kenaikan atau penurunan yang tidak terlalu signifikan pada setiap perusahaan. Bahkan terdapat dua perusahaan sub sektor semen yang mengalami kenaikan pada setiap tahunnya yaitu PT Indocement Tunggal Prakasa Tbk atau INTP dan PT Semen Indonesia (Persero) Tbk atau SMGR. Tingkat fluktuatif (kenaikan dan penurunan) EPS tentunya akan berpengaruh terhadap harga saham karena EPS merupakan penghasilan atas keuntungan yang akan diperoleh oleh pemegang saham per setiap lembar saham dan EPS dapat dijadikan signal bagi para investor sebelum berinvestasi.

2. Perkembangan ROE pada Perusahaan Sub Sektor Semen

Berdasarkan hasil penelitian yang dilakukan, perkembangan return on equity pada perusahaan sub sektor semen periode 20102014 adalah sebagai berikut:

Tabel 22.

Perkembangan Return On Equity (ROE)

Perusahaan Sub Sektor Semen Periode 2010-2014

(satuan persentase)

\begin{tabular}{|c|c|c|c|}
\hline Tahun & INTP & SMCB & SMGR \\
\hline $\mathbf{2 0 1 0}$ & 0.25 & 0.12 & 0.30 \\
\hline $\mathbf{2 0 1 1}$ & 0.23 & 0.14 & 0.27 \\
\hline $\mathbf{2 0 1 2}$ & 0.25 & 0.16 & 0.27 \\
\hline $\mathbf{2 0 1 3}$ & 0.22 & 0.11 & 0.25 \\
\hline $\mathbf{2 0 1 4}$ & 0.21 & 0.08 & 0.22 \\
\hline
\end{tabular}

(Sumber: www.idx.co.id diolah oleh penulis, Tahun 2016)

Dari tabel di atas, dapat disimpulkan bahwa adanya kenaikan dan penurunan pada return on equity yang tidak terlalu signifikan pada setiap tahunnya yaitu dari tahun 2010-2014. Terdapat satu perusahaan yang mengalami penurunan setiap tahunnya dalam mempergunakan sumber daya dalam menghasilkan laba atas ekuitas yaitu PT Semen Indonesia (Persero) Tbk atau SMGR.

3. Perkembangan ROA pada Perusahaan Sub Sektor Semen

Berdasarkan hasil penelitian yang dilakukan, perkembangan return on assets pada perusahaan sub sektor semen periode 20102014 adalah sebagai berikut:

Tabel 23.

Perkembangan Return On Assets (ROA)

Perusahaan Sub Sektor Semen Periode 2010-2014

(satuan persentase) 


\begin{tabular}{|c|c|c|c|}
\hline Tahun & INTP & SMCB & SMGR \\
\hline $\mathbf{2 0 1 0}$ & 0.21 & 0.08 & 0.24 \\
\hline $\mathbf{2 0 1 1}$ & 0.21 & 0.10 & 0.20 \\
\hline $\mathbf{2 0 1 2}$ & 0.23 & 0.11 & 0.19 \\
\hline $\mathbf{2 0 1 3}$ & 0.19 & 0.06 & 0.17 \\
\hline $\mathbf{2 0 1 4}$ & 0.18 & 0.04 & 0.16 \\
\hline
\end{tabular}

(Sumber: www.idx.co.id diolah oleh penulis, Tahun 2016)

Berdasarkan tabel, dapat disimpulkan bahwa return on assets perusahaan sub sektor semen mengalami fluktuasi setiap tahunnya. Penurunan dan kenaikan $R O A$ dipengaruhi oleh kemampuan perusahaan dalam mengelola setiap nilai aset yang dimiliki perusahaan untuk menghasilkan laba. Jika perusahaan mampu mengelola setiap nilai asetnya dengan baik maka $R O A$ akan naik. Sebaliknya jika perusahaan tidak mampu mengelola nilai setiap asetnya dengan baik maka $R O A$ akan turun. ROA tertinggi pada tahun 2010 sebesar 0,24 pada PT Semen Indonesia (Persero) Tbk atau SMGR dan yang Terendah pada tahun 2014 sebesar 0,04 pada PT Holcim Indonesia Tbk atau SMCB.

4. Perkembangan DER pada Perusahaan Sub Sektor Semen

Berdasarkan hasil penelitian yang dilakukan, perkembangan return on assets pada perusahaan sub sektor semen periode 20102014 adalah sebagai berikut:

Tabel 24.

Perkembangan Debt to Equity Ratio (DER) Perusahaan Sub Sektor Semen Periode 2010-2014

(dengan satuan persentase)

\begin{tabular}{|c|c|c|c|}
\hline Tahun & INTP & SMCB & SMGR \\
\hline $\mathbf{2 0 1 0}$ & 0.17 & 0.53 & 0.28 \\
\hline $\mathbf{2 0 1 1}$ & 0.15 & 0.45 & 0.35 \\
\hline $\mathbf{2 0 1 2}$ & 0.17 & 0.45 & 0.46 \\
\hline $\mathbf{2 0 1 3}$ & 0.16 & 0.70 & 0.41 \\
\hline $\mathbf{2 0 1 4}$ & 0.17 & 0.96 & 0.37 \\
\hline
\end{tabular}

(Sumber: $\underline{w w w . i d x . c o . i d ~ d i o l a h ~ o l e h ~ p e n u l i s, ~ T a h u n ~ 2015) ~}$

Berdasarkan tabel dapat disimpulkan bahwa debt to equity ratio perusahaan sub sektor semen berfluktuasi setiap tahunnya. Penurunan dan kenaikan debt to equity ratio dipengaruhi oleh jumlah utang yang dimiliki oleh perusahaan dan jumlah ekuitas perusahaan. Jika debt to equity ratio turun, maka menggambarkan bahwa perusahaan terus menekan untuk mengurangi penggunaan utang dari tahun ke tahun, dan perusahaan lebih meningkatkan penggunaan ekuitas. Namun jika debt to equity naik maka perusahaan memiliki utang yang lebih besar dari tahun sebelumnya. debt to equity ratio yang semakin kecil menunjukkan bahwa resiko 
ketidakmampuan perusahaan dalam membayar kewajibannya lebih kecil. Sebaliknya debt to equity ratio (DER) yang semakin besar menunjukkan bahwa resiko ketidakmampuan perusahaan dalam membayar kewajibannya cenderung lebih besar. DER tertinggi pada tahun 2014 sebesar 0,96 dan yang Terendah pada tahun 2011 sebesar 0,15.

\subsubsection{Perkembangan Harga Saham pada Perusahaan Sub Sektor Semen}

Harga saham adalah harga yang ditentukan oleh investor melalui pertemuan permintaan dan penawaran. Di samping itu, harga saham juga ditentukan oleh kondisi perusahaan yang bersangkutan artinya jika perusahaan memiliki kinerja yang baik, keuntungan yang dinikmati oleh pemegang saham dan semakin besar pula kemungkinan harga saham akan naik. Jika pasar bursa efek sudah tutup, maka harga pasar adalah harga penutupnya (closing price). Jadi harga pasar inilah yang menyatakan naik turunnya suatu saham. Berdasarkan hasil penelitian yang dilakukan, perkembangan harga saham pada perusahaan sub sektor semen periode 2010-2014 adalah sebagai berikut:

Tabel 25.

Perkembangan Harga Saham Perusahaan Sub Sektor Semen Periode 2010-2014 (dengan satuan rupiah)

\begin{tabular}{|c|c|c|c|}
\hline Tahun & INTP & SMCB & SMGR \\
\hline $\mathbf{2 0 1 0}$ & 16578 & 2026 & 9585 \\
\hline $\mathbf{2 0 1 1}$ & 18214 & 2453 & 12142 \\
\hline $\mathbf{2 0 1 2}$ & 23678 & 3832 & 17907 \\
\hline $\mathbf{2 0 1 3}$ & 24432 & 2860 & 16739 \\
\hline $\mathbf{2 0 1 4}$ & 22546 & 1521 & 13596 \\
\hline
\end{tabular}

(Sumber: www.yahoofinance diolah oleh penulis, Tahun 2016)

Dari tabel dapat dilihat bahwa semua perusahaan sub sektor semen mengalami penurunan harga saham pada tahun 2014. Penurunan harga saham dikarenakan oleh kinerja perusahaan yang kurang baik dalam hal profitabilitas dan solvabilitas. Profitabilitas yang dihasilkan yaitu ROE dan ROA mengalami penurunan di tahun 2014 sedangkan solvabilias yaitu DER mengalami kenaikan pada tahun 2014 yang berpengaruh terhadap peningkatan minat investor dalam investasi saham.

Beragamnya harga saham dikarenakan perbedaan jumlah permintaan dan penawaran akan saham suatu perusahaan. Apabila jumlah permintaan akan saham banyak maka harga saham akan naik, namun apabila permintaan saham rendah sedangkan penawaran saham naik atau tetap maka harga saham akan menurun.

\subsubsection{Uji Asumsi Klasik}

1. Uji Normalitas

Tabel 12.

Hasil Uji Normalitas Kolmogrov-Smirnov Test

\section{One-Sample Kolmogorov-Smirnov Test}




\begin{tabular}{|ll|r|}
\hline & & \multicolumn{2}{|c|}{$\begin{array}{c}\text { Unstandardized } \\
\text { Residual }\end{array}$} \\
\hline $\mathrm{N}$ & Mean & 15 \\
Normal Parameters & aE-7 \\
& Std. Deviation & .11111576 \\
Most Extreme & Absolute & .086 \\
Differences & Positive & .079 \\
& Negative & -.086 \\
Kolmogorov-Smirnov Z & .332 \\
Asymp. Sig. (2-tailed) & 1.000 \\
\hline
\end{tabular}

a. Test distribution is Normal.

b. Calculated from data.

(Sumber: Hasil Pengolahan Data dengan SPSS 20, Tahun 2016)

Berdasarkan tabel 12. di atas menunjukkan bahwa nilai signifikansi yang diperoleh yaitu 1,000. Karena nilai signifikansi yang dihasilkan berada di atas 0,05 , maka nilai residual tersebut telah normal.

2. Uji Heteroskedastisitas

Berikut ini hasil uji heteroskedastisitas dengan uji Spearman's rho :

Tabel 13.

Hasil Uji Heteroskedastisitas dengan Spearman's rho

\section{Correlations}

\begin{tabular}{|c|c|c|c|c|c|c|c|}
\hline & & & EPS & ROE & ROA & $\overline{\text { DER }}$ & $\begin{array}{c}\text { Unstandardized } \\
\text { Residual }\end{array}$ \\
\hline \multirow{13}{*}{$\begin{array}{l}\text { Spearman's } \\
\text { rho }\end{array}$} & \multirow{3}{*}{ EPS } & Correlation & 1.000 & .445 & $.610^{*}$ & $-.845^{* *}$ & -.139 \\
\hline & & Sig. (2-tailed) & & .096 & .016 & .000 & .621 \\
\hline & & $\mathrm{N}$ & 15 & 15 & 15 & 15 & 15 \\
\hline & \multirow{3}{*}{ ROE } & $\begin{array}{l}\text { Correlation } \\
\text { Coefficient }\end{array}$ & .445 & 1.000 & $.871^{* *}$ & -.512 & .065 \\
\hline & & Sig. (2-tailed) & .096 & & .000 & .051 & .819 \\
\hline & & $\mathrm{N}$ & 15 & 15 & 15 & 15 & 15 \\
\hline & \multirow{3}{*}{ ROA } & $\begin{array}{l}\text { Correlation } \\
\text { Coefficient }\end{array}$ & $.610^{*}$ & $.871^{* *}$ & 1.000 & $-.798^{* *}$ & -.018 \\
\hline & & Sig. (2-tailed) & .016 & .000 & & .000 & .950 \\
\hline & & $\mathrm{N}$ & 15 & 15 & 15 & 15 & 15 \\
\hline & \multirow{3}{*}{ DER } & $\begin{array}{l}\text { Correlation } \\
\text { Coefficient }\end{array}$ & $-.845^{* *}$ & -.512 & $-.798^{* *}$ & 1.000 & 280 \\
\hline & & Sig. (2-tailed) & .000 & .051 & .000 & & .312 \\
\hline & & $\mathrm{N}$ & 15 & 15 & 15 & 15 & 15 \\
\hline & $\begin{array}{l}\text { Unstandardized } \\
\text { Residual }\end{array}$ & $\begin{array}{l}\text { Correlation } \\
\text { Coefficient }\end{array}$ & -.139 & .065 & -.018 & .280 & 1.000 \\
\hline
\end{tabular}

JIAFE (Jurnal Ilmiah Akuntansi Fakultas Ekonomi)

Volume 2 No. 1 Tahun 2016 Edisi 1, Hal. 1-22 


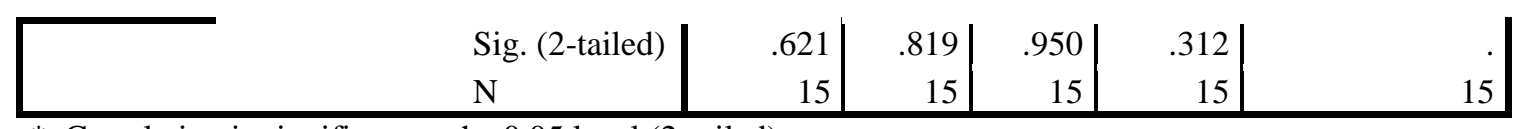

*. Correlation is significant at the 0.05 level (2-tailed).

**. Correlation is significant at the 0.01 level (2-tailed).

(Sumber: Hasil Pengolahan Data dengan SPSS 20, Tahun 2016)

Dari data di atas dapat dilihat bahwa korelasi semua variabel independen dengan Unstandardized Residual menghasilkan nilai signifikansi >
0,05, sehingga dapat disimpulkan bahwa pada model regresi tidak ditemukan adanya masalah heteroskedastisitas.

3. Uji Multikolineritas

Berikut ringkasan tabel hasil uji multikolineritas :

Tabel 15.

Hasil Uji Multikolinearitas (Perbandingan $\mathrm{r}^{2}$ dengan $\mathrm{R}^{2}$ )

\begin{tabular}{|c|c|c|}
\hline Variabel Dependen & Variabel Independen & Nilai $r$ square $\left(\mathrm{r}^{2}\right)$ \\
\hline X1 (EPS) & X2 (ROE) & 0.770 \\
X1 (EPS) & X3 (ROA) & 0.812 \\
X1 (EPS) & X4 (DER) & 0.678 \\
X2 (ROE) & X3 (ROA) & 0.957 \\
X2 (ROE) & X4 (DER) & 0.492 \\
X3 (ROA) & X4 (DER) & 0.678 \\
\hline Nilai R R $^{2}$ & & 0.988 \\
\hline
\end{tabular}

(Sumber: Hasil Pengolahan Data dengan SPSS 20, Tahun 2016)

Berdasarkan tabel di atas menunjukkan bahwa semua nilai koefisien Determinasi Individual $\left(\mathrm{r}^{2}\right)$ lebih kecil nilai Determinasi secara serentak $\left(\mathrm{R}^{2}\right)$, maka dapat disimpulkan bahwa bahwa pada model regresi tidak ditemukan adanya masalah multikolinieritas.

4. Uji Autokorelasi

Berikut ini hasil uji autokorelasi terkait dengan harga saham sebagai variabel dependen.

Tabel 16.

Hasil Uji Run Test

Runs Test

\begin{tabular}{|l|r|}
\hline & $\begin{array}{c}\text { Unstandardized } \\
\text { Residual }\end{array}$ \\
\hline Test Value $^{\mathrm{a}}$ & -.00047 \\
Cases < Test Value & 7 \\
Cases >= Test Value & 8 \\
Total Cases & 15 \\
Number of Runs & 6
\end{tabular}




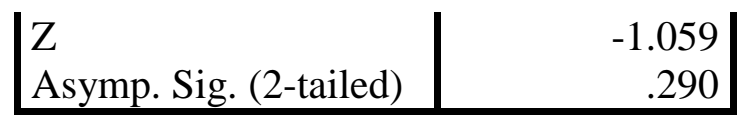

a. Median

(Sumber: Hasil Pengolahan Data dengan SPSS 20, Tahun 2016)

Berdasarkan tabel di atas dapat dilihat bahwa nilai Asymp. Sig. (2-tailed) $>0,05$ yang berarti hipotesis nol gagal ditolak. Dengan demikian data yang dipergunakan cukup random sehingga tidak terdapat masalah autokorelasi.

\subsubsection{Analisis Regresi Linier Berganda}

Tabel 17.

Coefficients $^{\mathrm{a}}$

Hasil Uji Analisis Regresi Linier Berganda

\begin{tabular}{|c|c|c|c|c|c|c|}
\hline & \multirow[t]{2}{*}{ Model } & \multicolumn{2}{|c|}{$\begin{array}{c}\text { Unstandardized } \\
\text { Coefficients } \\
\end{array}$} & $\begin{array}{c}\text { Standardized } \\
\text { Coefficients }\end{array}$ & \multirow[t]{2}{*}{$\mathrm{T}$} & \multirow[t]{2}{*}{ Sig. } \\
\hline & & $\mathrm{B}$ & Std. Error & Beta & & \\
\hline \multirow{5}{*}{1} & (Constant) & 3.505 & .764 & & 4.586 & .001 \\
\hline & EPS & .879 & .102 & .914 & 8.634 & .000 \\
\hline & ROE & 1.126 & 1.172 & .444 & .961 & .359 \\
\hline & $\mathrm{ROA}$ & -.883 & .998 & -.478 & -.885 & .397 \\
\hline & DER & -.249 & .304 & -.146 & -.820 & .431 \\
\hline
\end{tabular}

a. Dependent Variable: HARGA SAHAM

(Sumber: Hasil Pengolahan Data dengan SPSS 20, Tahun 2016)

Berdasarkan hasil analisis di atas, maka dapat dibuat model persamaan regresi linear berganda sebagai berikut:

$$
\mathrm{Y}=\mathrm{a}+\mathrm{b}_{1} \mathrm{X}_{1}+\mathrm{b}_{2} \mathrm{X}_{2}+\mathrm{b}_{3} \mathrm{X}_{3}+\mathrm{b}_{4} \mathrm{X}_{4}
$$

Harga Saham $=3,505+0,879$ EPS + $1,126 R O E+(-0,883) R O A+(-0,249)$ DER

Interpretasi dari persamaan model regresi linier berganda di atas adalah sebagai berikut:

\section{Konstanta}

Nilai konstanta (a) adalah 3,505. Artinya, jika variabel independen yaitu $E P S, R O E, R O A$ dan $D E R$ nilainya adalah nol, maka nilai variabel dependen yaitu harga saham nilainya positif yaitu sebesar 3,505.

2. Koefisien Regresi Variabel Earning Per Share (EPS)
Nilai koefisien regresi variabel EPS $\left(\mathrm{b}_{1}\right)$ bernilai positif, yaitu sebesar 0,879. Hal ini menunjukkan bahwa setiap peningkatan EPS sebesar satu satuan, maka harga saham juga akan meningkat sebesar 0,879 dengan asumsi bahwa variabel independen lainnya dalam model regresi ini nilainya tetap.

Koefisien bertanda positif, hal ini menunjukkan bahwa EPS berhubungan positif dengan harga saham pada perusahaan sub sektor semen yang terdaftar di BEI. Dari koefisien EPS tersebut maka dapat disimpulkan bahwa jika EPS bernilai positif maka harga saham pun akan naik.

3. Koefisien Regresi Variabel Return On Equity (ROE) 
Nilai koefisien regresi variabel $R O E\left(\mathrm{~b}_{2}\right)$ bernilai positif, yaitu sebesar 1,126. Hal ini menunjukkan bahwa setiap peningkatan ROE sebesar satu satuan, maka harga saham juga akan meningkat sebesar 1,126 dengan asumsi bahwa variabel independen lainnya dalam model regresi ini nilainya tetap.

Koefisien ROE bertanda positif. Hal ini menunjukkan bahwa ROE berhubungan positif dengan harga saham pada perusahaan sub sektor semen yang terdaftar di BEI. Dari koefisien $R O E$ tersebut maka dapat disimpulkan bahwa jika $R O E$ bernilai positif maka harga saham pun akan naik.

4. Koefisien Regresi Variabel Return On Assets (ROA)

Nilai koefisien regresi variabel $R O A\left(\mathrm{~b}_{3}\right)$ bernilai negatif, yaitu sebesar -0,883. Hal ini menunjukkan bahwa ROA memiliki hubungan yang berlawanan arah dengan harga saham. Setiap kenaikan ROA sebesar satu satuan, maka harga saham pun akan menurun sebesar 0,883 dengan asumsi bahwa variabel independen lainnya dalam model regresi ini nilainya tetap.

Koefisien ROA bertanda negatif. Hal ini menujukkan bahwa $R O A$ berhubungan negatif terhadap harga saham pada perusahaan sub sektor semen yang terdaftar di BEI.

5. Koefisien Regresi Variabel Debt to Equity Ratio (DER)

Nilai koefisien regresi variabel $D E R\left(\mathrm{~b}_{4}\right)$ bernilai negatif, yaitu sebesar -0,249. Hal ini menunjukkan bahwa DER memiliki hubungan yang berlawanan arah dengan harga saham. Setiap kenaikan DER sebesar satu satuan, maka harga saham pun akan menurun sebesar 0,249 dengan asumsi bahwa variabel independen lainnya dalam model regresi ini nilainya tetap.

Koefisien DER bertanda negatif. Hal ini menujukkan bahwa $D E R$ berhubungan negatif terhadap harga saham pada perusahaan sub sektor semen yang terdaftar di BEI.

4.1.5. Pengaruh EPS, ROE, ROA dan DER terhadap Harga Saham pada Perusahaan Sub Sektor Semen yang Terdaftar di BEI

1. Uji Koefisien Determinasi

Tabel 18.

Koefisien Determinasi

Model Summary

\begin{tabular}{|l|r|r|r|r|}
\hline Model & \multicolumn{1}{|c|}{$\mathrm{R}$} & $\mathrm{R}$ Square & $\begin{array}{c}\text { Adjusted R } \\
\text { Square }\end{array}$ & $\begin{array}{r}\text { Std. Error of } \\
\text { the Estimate }\end{array}$ \\
\hline 1 & $.994^{\mathrm{a}}$ & .988 & .983 & .13147 \\
\hline
\end{tabular}

a. Predictors: (Constant), EPS, ROE, ROA, DER

(Sumber: Hasil Pengolahan Data dengan SPSS 20, Tahun 2016)

Berdasarkan koefisien

determinasi pada Tabel 18.

diperoleh angka $\mathrm{R}^{2}$ (R Square)

sebesar 0,988 atau $(98,8 \%)$. Hal ini

menunjukkan bahwa presentase sumbangan pengaruh variabel independen (earning per share, return on equity, return on assets dan debt to equity ratio) sebesar 98,8\%. Atau variasi variabel 
independen yang digunakan dalam model (earning per share, return on equity, return on assets dan debt to equity ratio) mampu menjelaskan sebesar $98,8 \%$ terhadap variasi variabel dependen (harga saham). Sedangkan sisanya sebesar $1,2 \%$ dipengaruhi atau dijelaskan oleh variabel lain yang tidak dimasukkan dalam model penelitian ini.

2. Uji Koefisien secara Parsial (Uji t)

Tabel 19.

Coefficients $^{\mathrm{a}}$

Hasil Uji t

\begin{tabular}{|c|c|c|c|c|c|c|}
\hline & \multirow[t]{2}{*}{ Model } & \multicolumn{2}{|c|}{$\begin{array}{l}\text { Unstandardized } \\
\text { Coefficients }\end{array}$} & $\begin{array}{l}\text { Standardized } \\
\text { Coefficients }\end{array}$ & \multirow[t]{2}{*}{$\mathrm{t}$} & \multirow[t]{2}{*}{ Sig. } \\
\hline & & $\mathrm{B}$ & Std. Error & Beta & & \\
\hline \multirow{5}{*}{1} & (Constant) & 3.505 & .764 & & 4.586 & .001 \\
\hline & EPS & .879 & .102 & .914 & 8.634 & .000 \\
\hline & ROE & 1.126 & 1.172 & .444 & .961 & .359 \\
\hline & $\mathrm{ROA}$ & -.883 & .998 & -.478 & -.885 & .397 \\
\hline & DER & -.249 & .304 & -.146 & -.820 & .431 \\
\hline
\end{tabular}

a. Dependent Variable: HARGA SAHAM

(Sumber: Hasil Pengolahan Data dengan SPSS 20, Tahun 2016)

Berdasarkan analisis uji $\mathrm{t}$ pada tabel 19. adalah sebagai berikut:

a. Earning per share $\left(\mathrm{X}_{1}\right)$ terhadap Harga Saham (Y)

Berdasarkan

signifikansi, jika signifikansi $<0,05$ maka $\mathrm{H} 1$ diterima, dan jika signifikansi $>0,05$ maka H1 ditolak. Pada tabel 19. terlihat bahwa signifikansi yang dihasilkan yaitu 0,000 dan $t_{\text {hitung }}=8,634$. Karena signifikansi pada uji t kurang dari $\quad 0,05 \quad(0,000<0,05)$ dimana nilai $\quad\left(\mathrm{t}_{\text {hitung }}>\mathrm{t}_{\text {tabel }}\right)$ (8,634> 2.22814) maka H1 diterima. Dengan demikian dapat disimpulkan bahwa EPS secara parsial berpengaruh positif terhadap harga saham.

b. Return on equity $\left(\mathrm{X}_{2}\right)$ terhadap Harga Saham (Y)

Berdasarkan signifikansi, jika signifikansi $<0,05$ maka H1 diterima, dan jika signifikansi >0,05 maka H1 ditolak. Pada tabel 19. terlihat bahwa signifikansi yang dihasilkan yaitu 0,359 dan $t_{\text {hitung }}=0,961$. Karena signifikansi pada uji t lebih dari $\quad 0,05 \quad(0,359>0,05)$ dimana nilai $\left(\mathrm{t}_{\text {hitung }}<\mathrm{t}_{\text {tabel }}\right)$ $(0,961<2,22814)$ maka H1 ditolak. Dengan demikian dapat disimpulkan bahwa ROE secara parsial tidak berpengaruh terhadap harga saham.

c. Return On Assets $\left(\mathrm{X}_{3}\right)$ terhadap Harga Saham (Y) Berdasarkan signifikansi, jika signifikansi $<0,05$ maka $\mathrm{H} 1$ diterima, dan jika signifikasi >0,05 maka H1 ditolak. Pada tabel 19. terlihat bahwa signifikansi yang dihasilkan yaitu 0,397 dan $t_{\text {hitung }}=-0,885$. Karena signifikansi pada uji t lebih dari $\quad 0,05 \quad(0,397>0,05)$ dimana nilai $\left(-t_{\text {hitung }}>-t_{\text {tabel }}\right)(-$ 
0,885>-2,22814) maka H1 ditolak. Dengan demikian dapat disimpulkan bahwa $R O A$ secara parsial tidak berpengaruh terhadap harga saham.

d. Debt to equity ratio $\left(\mathrm{X}_{4}\right)$ terhadap Harga Saham (Y)

Berdasarkan signifikansi, jika signifikansi $<0,05$ maka $\mathrm{H} 2$ diterima, dan jika signifikansi $>0,05$ maka $\mathrm{H} 2$ ditolak. Pada tabel di atas

4. terlihat bahwa signifikansi yang dihasilkan yaitu 0,431 dan $t_{\text {hitung }}=-0,820$. Karena signifikansi pada uji $\mathrm{t}$ lebih dari $\quad 0,05 \quad(0,431>0,05)$ dimana nilai $\left(-\mathrm{t}_{\text {hitung }}>-\mathrm{t}_{\text {tabel }}\right)(-$ $0,820>-2,22814)$ maka $\mathrm{H} 2$ ditolak. Dengan demikian dapat disimpulkan bahwa DER secara parsial tidak berpengaruh terhadap harga saham.

3. Uji Koefisien Regresi Secara

Bersama-sama (Uji F)

Tabel 20.

Hasil Uji F

ANOVA ${ }^{\mathrm{a}}$

\begin{tabular}{|r|r|r|r|c|c|}
\hline \multicolumn{1}{|c|}{ Model } & Sum of Squares & Df & Mean Square & F & Sig. \\
\hline \multirow{4}{*}{1} & 13.684 & 4 & 3.421 & 197.906 & $.000^{\mathrm{b}}$ \\
Regression & .173 & 10 & .017 & & \\
Residual & 13.856 & 14 & & & \\
\hline
\end{tabular}

a. Dependent Variable: HARGA SAHAM

b. Predictors: (Constant), EPS, ROE, ROA, DER

(Sumber: Hasil Pengolahan Data dengan SPSS 20, Tahun 2016)

Berdasarkan analisis uji $\mathrm{F}$ pada tabel 20. dapat dilihat bahwa secara simultan variabel independen memiliki nilai sig < 0,05 yakni 0,000 dan $F_{\text {hitung }}$ sebesar 197,906. Dengan menggunakan tingkat keyakinan 95\%, $\alpha=5 \%$, df 1 (jumlah variabel-1) $=4$, dan df 2 (n-k-1) atau 15-4-1 = 10 (n adalah jumlah kasus dan $\mathrm{k}$ adalah jumlah variabel independen), hasil diperoleh untuk $F_{\text {tabel }}$ sebesar 3,48. Dengan demikian nilai $F_{\text {hitung }}$ 197,906 $>F_{\text {tabel }}$ 3,48. Sehingga dapat disimpulkan bahwa variabel independen dalam penelitian ini, yaitu earning per share $\left(\mathrm{X}_{1}\right)$, return on equity $\left(\mathrm{X}_{2}\right)$, return on assets $\left(\mathrm{X}_{3}\right)$ dan debt to equity ratio $\left(\mathrm{X}_{4}\right)$ secara simultan berpengaruh positif terhadap harga saham (Y).

\subsection{Interpretasi Hasil Penelitian}

Berdasarkan hasil penelitian ini, varibel independen (EPS, ROE, ROA dan $D E R)$ secara bersama-sama berpengaruh terhadap harga saham. Adapun koefisien determinasi sebesar $98,8 \%$ yang artinya harga saham dapat dijelaskan oleh $E P S$, $R O E, R O A$ dan DER selebihnya $1,2 \%$ dipengaruhi oleh variabel lain diluar penelitian ini. Hal ini sama dengan penelitian yang dilakukan oleh Debi Indah (2012) yang menyimpulkan bahwa EPS, ROE, ROA dan DER memiliki hubungan yang kuat terhadap harga saham dan berpengaruh secara signifikan terhadap harga saham. Berdasarkan hasil penelitian yang dilakukan bahwa variabel fundamental seperti $E P S, R O E$, $R O A$ dan DER secara simultan atau 
bersama-sama memiliki pengaruh yang positif terhadap harga saham.

Earning per share secara parsial berpengaruh positif terhadap harga saham. Earning per share atau laba per lembar saham merupakan ukuran kemampuan perusahaan untuk menghasilkan keuntungan per lembar saham pemilik (Kasmir, 2014, 207). Hal ini berarti earning per share yang meningkat menunjukan perusahaan mampu meningkatkan keuntungan para pemegang saham, sehingga harga saham akan meningkat. Selain itu, hasil penelitian ini konsisten dengan penelitian yang dilakukan oleh Taranika Intan (2009) dan Debi Indah (2012) yang menyatakan bahwa EPS berpengaruh terhadap harga saham.

Return on equity secara parsial tidak berpengaruh terhadap harga saham. Rasio ini berguna untuk mengetahui besarnya pengembalian yang diberikan oleh perusahaan untuk setiap rupiah modal pemilik. Rasio ini menunjukan kesuksesan manajemen dalam memaksimalkan tingkat kembalian yang lebih besar kepada pemegang saham (Irham Fahmi, 2014, 338). Hal ini berarti return on equity yang rendah menunjukan bahwa manajemen belum mampu memaksimalkan dana pemegang saham dalam menjalankan operasi perusahaan secara efektif dan efisien. Hasil penelitian ini konsisten dengan penelitian yang dilakukan oleh Debi Indah (2012) yang menyatakan bahwa $R O E$ tidak berpengaruh terhadap harga saham.

Return On Assets secara parsial tidak berpengaruh terhadap harga saham. Tingkat laba atas ekuitas mengukur keuntungan yang dihasilkan dari aktiva dalam usaha. Tingkat laba atas aktiva yang rendah menunjukkan kinerja yang buruk atau pemanfaatan aktiva yang buruk oleh manajemen. Tingkat laba yang tinggi menunjukan kinerja dan penggunaan aktiva yang baik (Heri, 2015, 193). Hasil penelitian ini tidak konsisten dengan penelitian yang dilakukan oleh Ema Novasari (2013) yang menyatakan bahwa secara parsial $R O A$ mempunyai pengaruh yang signifikan terhadap harga saham.

Debt to equity ratio secara parsial tidak berpengaruh terhadap harga saham. Rasio ini dihitung sebagai hasil bagi antara total utang dengan modal. Rasio ini berguna untuk mengetahui besarnya perbandingan antara jumlah dana yang disediakan oleh kreditor dengan jumlah dana yang berasal dari pemilik perusahaan. Dengan kata lain, rasio ini berfungsi untuk mengetahui berapa bagian dari setiap rupiah modal yang dijadikan sebagai jaminan utang. Rasio ini memberikan petunjuk umum tentang kelayakan kredit dan risiko keuangan debitor (Hery, 2015,168). Hasil penelitian ini tidak konsisten dengan penilitian yang dilakukan oleh Ema Novasari (2013) yang menunjukan bahwa variabel $D E R$ secara parsial memiliki pengaruh positif terhadap harga saham.

\section{Penutup}

1. Perkembangan earning per share (EPS) pada perusahaan sub sektor semen yang terdaftar di BEI dari tahun 2010-2014 mengalami tingkat kenaikan dan penurunan yang tidak terlalu signifikan. Nilai EPS cenderung naik, kecuali pada perusahaan PT Holcim Indonesia Tbk atau SMCB mengalami penurunan nilai EPS pada tahun 2013-2014. EPS dijadikan informasi bagi para investor sebelum berinvestasi. Nilai EPS mencerminkan seberapa besar keuntungan yang akan diperoleh oleh investor. Perkembangan 
return on equity (ROE) yang dihasilkan dari perusahaan sub sektor semen yang terdaftar di BEI dari tahun 2010-2014 cenderung berfluktuasi. Fluktuasi ini akan berdampak pada keputusan investor dalam melakukan investasi. Hal ini disebabkan oleh naik turunnya earning after tax dan jumlah modal sendiri yang dimliki oleh perusahaan. Perkembangan return on assets (ROA) pada perusahaan sub sektor semen yang terdaftar di BEI dari tahun 2010-2014 cenderung mengalami penurunan. Penurunan ini disebabkan oleh turunnya earning after tax. Perkembangan debt to equity ratio (DER) pada perusahaan sub sektor semen yang terdaftar di BEI dari tahun 20102014 cenderung berfluktuasi. Fluktuasi ini akan berdampak pada keputusan investor dalam melakukan investasi. Apabila $D E R$ perusahaan tinggi, ada kemungkinan harga saham akan rendah karena jika perusahaan memperoleh laba, maka perusahaan cenderung menggunakan laba tersebut untuk membayar utangnya dibandingkan dengan membagi dividen.

2. Perkembangan harga saham pada perusahaan sub sektor semen yang terdaftar di BEI dari tahun 20102014 mengalami fluktuatif. Hal ini dikarenakan adanya perbedaan permintaan dan penawaran saham pada perusahaan tersebut. Apabila jumlah permintaan akan saham banyak maka harga saham akan naik, namum apabila permintaan saham rendah sedangkan penawaran saham naik atau tetap maka saham akan turun.

3. Setelah melakukan pengujian earning per share secara parsial, hasil dari pengujian tersebut ialah earning per share berpengaruh positif terhadap harga saham pada perusahaan sub sektor semen yang terdaftar di Bursa Efek Indonesia (BEI) periode 2010-2014. Sehingga dapat disimpulkan bahwa hipotesis $\mathrm{H} 1$ untuk variabel earning per share terbukti. Sedangkan untuk return on equity, return on assets dan debt to equity ratio secara parsial tidak berpengaruh terhadap harga saham. Sehingga dapat disimpulkan bahwa hipotesis $\mathrm{H} 1$ dan $\mathrm{H} 2$ untuk variabel return on equity, return on assets dan debt to equity ratio tidak terbukti.

4. Hasil pengujian simultan earning per share (EPS), return on equity (ROE), return on assets (ROA) dan debt to equity ratio (DER) secara bersama-sama berpengaruh positif terhadap harga saham pada perusahaan semen yang terdaftar di Bursa Efek Indonesia (BEI) periode 2010-2014. Hal ini menunjukkan bahwa hipotesis $\mathrm{H} 3$ terbukti. 